\title{
Efficiency of methods to detect Sclerotinia sclerotiorum in commercial soybean seed lots ${ }^{1}$
}

\author{
Luciane Henneberg ${ }^{2 *}$, David de S. Jaccoud Filho ${ }^{3}$, \\ Lucimeris Ruaro $^{2}$, Maristela Panobianco ${ }^{2}$
}

\begin{abstract}
Most soybean pathogens are seed transmitted, deserving emphasis the fungus Sclerotinia sclerotiorum, which has been presenting worrying levels of field incidence in some soybean cropping areas in several Brazilian states. The objective of this study was to verify the efficiency of different methods for detecting S. sclerotiorum on soybean seeds artificially infected in the laboratory and from field production areas with a historical disease incidence. Seed samples of seven different cultivars collected from naturally infested fields, and one seed sample artificially inoculated in the laboratory were used. The following detection methods recommended in the literature were compared: Blotter test at $7{ }^{\circ} \mathrm{C}, 14^{\circ} \mathrm{C}$, and $21^{\circ} \mathrm{C}$; Rolled Paper; and Neon-S. Results demonstrated that these methods showed no repeatability and had a low sensitivity for detecting the pathogen in seeds from areas with disease incidence. They were effective, however, for its detection on artificially inoculated seeds. In the Blotter test method at $7{ }^{\circ} \mathrm{C}$, there was a lower incidence of other fungi considered undesirable during seed analysis.
\end{abstract}

Index terms: Glycine max, seed health, white mold, seed quality.

\section{Eficiência de métodos para detecção de Sclerotinia sclerotiorum em lotes de sementes comerciais de soja}

RESUMO - A maioria dos patógenos de soja é transmitida pela semente, merecendo destaque o fungo Sclerotinia sclerotiorum, o qual tem apresentando níveis preocupantes de incidência em campo, em vários estados brasileiros. O trabalho teve por finalidade verificar a eficiência de métodos de detecção do patógeno Sclerotinia sclerotiorum em sementes de soja, infectadas artificialmente em laboratório e oriundas de áreas com o histórico da incidência da doença em campo. Para tanto, foram utilizadas amostras de sementes de sete cultivares, provenientes de áreas infestadas e uma amostra de sementes inoculada artificialmente. Foram comparados os seguintes métodos de detecção recomendados pela literatura: Papel de Filtro ("Blotter Test"), a $7{ }^{\circ} \mathrm{C}, 14{ }^{\circ} \mathrm{C}$ e $20^{\circ} \mathrm{C}$; Rolo de Papel; e Neon-S. Pelos resultados obtidos, verificou-se que os métodos estudados não apresentaram repetibilidade, sendo pouco sensíveis para a detecção do patógeno em sementes provenientes de áreas com incidência da doença; porém, foram eficientes para a detecção em sementes inoculadas artificialmente. No método de incubação em Papel de Filtro a $7{ }^{\circ} \mathrm{C}$ observou-se menor incidência de outros fungos considerados indesejáveis durante as análises de sementes realizadas.

Termos para indexação: Glycine max, sanidade de sementes, mofo branco, qualidade de sementes.

${ }^{1}$ Submitted on 04/29/2011. Accepted for publication on 08/26/2011.

${ }^{2}$ Departamento de Fitotecnia e Fitossanitarismo, Universidade Federal do Paraná, Rua dos Funcionários n ${ }^{\circ}$ 1540, 80035-050 - Curitiba, PR, Brasil.
${ }^{3}$ Departamento de Fitotecnia e Fitossanidade, UEPG, Avenida Carlos Cavalcanti, 4748, 84030-900 - Ponta Grossa, PR, Brasil.

*Corresponding author $<$ lucihenne@hotmail.com> 


\section{Introduction}

The soybean complex (grain, meal, and oil) is one of the main sectors that significantly contribute for the Brazilian agribusiness exports (CONAB, 2011).

Brazil is the second worldwide producer of this oilseed. The soybean production in the 2009/10 crop season had a $20 \%$ increase as compared to the prior season, being estimated an increment of approximately five million metric tons for the 2010/11 crop season. The State of Paraná ranks the first national output position, corresponding to $19 \%$ of the nationwide seed production (Embrapa, 2008; CONAB, 2011).

The sanitary factor, by controlling seed transmitted diseases is relevant in the agricultural production, since the damages arising from the pathogen/seed association result in the reduction of seedling emergence and productivity (Jaccoud Filho et al., 2002).

On the soybean crop, the disease commonly known as white mold, caused by the fungus Sclerotinia sclerotiorum (Lib.) de Bary, which in the last years has lead to losses ranging from $11.5 \%$ to $96.0 \%$ in the Southern region of Paraná State (Jaccoud Filho et al., 2010) deserves emphasis.

The seed is the main dissemination vehicle. On its transmission, however, only the presence of sclerotia among seeds has been commonly considered. According to Decree No. 47 of February 26, 2009, from the Secretaria de Defesa Agropecuária do Ministério da Agricultura, Pecuária e Abastecimento (Secretariat of Agricultural Defense of the Ministry of Agriculture, Livestock and Food Supply) the level of tolerance for this fungus in seed lots is based on the presence of sclerotia. Nevertheless, the seed may be internally infected by S. sclerotiorum (Yang et al., 1998) or externally infected by fungal hyphae segments located within the hourglass layer of the seed coat (Soave and Wetzel, 1987; Zambolim, 2005). For Steadman (1983), a seed infected by this pathogen produces more than one sclerotium and each individual structure, per se, is able to produce 20 apothecia with individual capacity of liberating 2,000,000 ascospores in 10 days. Therefore, one single seed has the probability of producing a minimum of 2,000,000 infection sites.

Within this context, the search for an adequate protocol for diagnosing the fungus Sclerotinia sclerotiorum in seeds became necessary, since reductions on the agricultural production have been observed; besides the fact of being the seed the main dissemination vehicle (Embrapa, 2008; Jaccoud-Filho et al., 2010).

There are several different methods for detecting Sclerotinia sclerotiorum on the seed with dissimilarities in sensitivity, repeatability, economy, and swiftness for results achievement (Machado, 2000; Henning, 2005).

A method widely used among seed pathology laboratories for detecting S. sclerotiorum on seeds of common bean, sunflower, peas, and soybean is the Blotter Test (Brasil, 2009), being recommended temperatures between $10^{\circ} \mathrm{C}$ and $15^{\circ} \mathrm{C}$ for an incubation period of 14 days. The conditions for sclerotia formation, however, are very variable. Under low light intensity conditions $\left(89 \mathrm{~mol} . \mathrm{m}^{-2} \mathrm{~s}^{-1}\right.$ to $90 \mathrm{~mol} \cdot \mathrm{m}^{-2} \mathrm{~s}^{-1}$ ) the optimal temperature for sclerotia growth is between $12^{\circ} \mathrm{C}$ and $18^{\circ} \mathrm{C}$, without moisture influence; but under high light intensity conditions ( $120 \mathrm{~mol} \cdot \mathrm{m}^{-2} \mathrm{~s}^{-1}$ to $\left.130 \mathrm{~mol} \cdot \mathrm{m}^{-2} \mathrm{~s}^{-1}\right)$ the optimal temperature for their development is $20^{\circ} \mathrm{C}$, with the addition of a $\mathrm{H}_{2} \mathrm{O}$ quantity ranging from $670 \mathrm{~mL}$ to $700 \mathrm{~mL}$ for an amount of $4 \mathrm{~kg}$ of sand, leading to the formation of a water pellicle over the sand (Sun and Yang, 2000). It is also found in the literature some suggestions on incubation temperatures varying from $7{ }^{\circ} \mathrm{C}$ to $20{ }^{\circ} \mathrm{C}$, and incubation periods varying from 10 to 30 days (Koch and Menten, 2000; APASSUL, 2008).

Parisi et al. (2006) described the Paper Roll incubation method, presenting as a disadvantage the difficulties in separating the infected seeds from the healthy ones, i.e. infected seeds can contaminate the surrounding healthy seeds, thus overestimating the incidence of the pathogen $S$. sclerotiorum in the seed lot.

In turn, the Neon method (Brasil, 2009) consists in the use of a $\mathrm{pH}$ indicator in the culture medium, which becomes yellowish due to the liberation of oxalic acid by the $S$. sclerotiorum fungus. Some fungi such as Rhizophus sp. and Aspergillus spp. are also acid producers making the aid of a stereomicroscope a necessity for a better distinction among them (Napoleão et al., 2006).

Despite the availability of other various different methods in the literature, as the ones described in the prior paragraphs, there are no studies on the efficiency of these methods in detecting $S$. sclerotiorum in commercial soybean seeds lots.

In light of the foregoing, this research work had the objective of verifying the efficiency of the pathogen Sclerotinia sclerotiorum detection methods in soybean seeds artificially infected in the laboratory and in soybean seeds produced within areas with previous history of the disease field incidence. 


\section{Material and Methods}

The research work was carried out in the Seed Pathology Laboratory of the Departamento de Fitotecnia e Fitossanidade da Universidade Estadual de Ponta Grossa (UEPG) (Department of Plant Technology and Plant Health of the State University of Ponta Grossa) municipality of Ponta Grossa, State of Paraná, Southern Brazil, from June 2009 to September 2010.

Seed samples of seven different soybean cultivars obtained from field areas with a historic incidence of S. sclerotiorum and one sample of healthy seeds, which was then artificially inoculated in the laboratory, were used for the experiment.

The following soybean cultivars were used:

a) 2008/2009 crop season: CD 231RR and BRS 255RR, produced in the municipalities of Ponta Grossa region; CD 219RR, of Teixeira Soares region; and CD 206, of Carambeí region;

b) 2009/2010 crop season: BRS 255RR, from the municipalities of Ipiranga region; and Spring RR and Don Mario 5.8iRR, from Arapoti region.

The seed samples obtained in the regions infested with the fungus $S$. sclerotiorum were collected at harvesting time.

For analysis of the healthy seed sample, which was then artificially inoculated in the laboratory, the cultivar CD 206 collected in a S. sclerotiorum free area in the municipality of Ponta Grossa region [(Fazenda Escola da Universidade Estadual de Ponta Grossa) (School Farm of the State University of Ponta Grossa)] was used. The inoculation was performed according to the method cited by Machado et al. (2001) that consists in placing 200 healthy soybean seeds into $9 \mathrm{~cm}$ in diameter Petri dishes containing the fungus S. sclerotiorum grown on PDA (Potato-Dextrose-Agar) medium, for 14 days, with the seeds remaining in contact with the fungal mycelia for $48 \mathrm{~h}$ and then incubated into a BOD type incubator, at $20{ }^{\circ} \mathrm{C}$ temperature, under continuous dark. The seeds so inoculated were removed from the Petri dishes and allowed to dry under room temperature.

For each cultivar studied, $10 \mathrm{~kg}$ of seeds were collected. The samples were then homogenized using a mechanical method that consisted in dividing the samples into two parts approximately equal and homogeneous, which were then passed two times through a soil divider, with the removal of half the portion and subsequently recomposing the remaining lot. The successive division process was repeated until obtaining four working subsamples with $2.5 \mathrm{~kg}$ each (Brasil, 2009).

After that procedure, the samples were placed into kraft paper bags and stored under $12{ }^{\circ} \mathrm{C}$ temperature and $48 \% \mathrm{RH}$. The homogenization of seeds was performed by manual agitation every time seed samples were removed for analysis.

The following seed health tests were compared:

a) Blotter Test at $7{ }^{\circ} \mathrm{C}$ : plastic containers measuring $11 \mathrm{~cm}$ x $11 \mathrm{~cm}$ x $3.5 \mathrm{~cm}$, known as "gerbox", previously disinfected with $5 \%$ sodium hypochlorite, containing as substrate two sheets of $80 \mathrm{~g} . \mathrm{m}^{-2}$ filter paper, measuring $10 \mathrm{~cm} \times 10 \mathrm{~cm}$ each, which had been sterilized in an autoclave at $120{ }^{\circ} \mathrm{C}$ and $1 \mathrm{~atm}$ pressure, for 20 minutes. Subsequently, sterile $\mathrm{H}_{2} \mathrm{O}$ was added in a proportion of 2.5 times the mass of the paper and, on top of such substrate, soybean seeds randomly chosen were arranged in a $5 \times 4$ format, obtaining 20 gerbox containing 20 seeds each, thus totaling 400 seeds. Those seeds were then incubated at $7{ }^{\circ} \mathrm{C}$, for 30 days, under continuous dark;

b) Blotter Test at $14{ }^{\circ} \mathrm{C}$ : this test was performed using the same methodology described for the item (a), although being incubated at $14{ }^{\circ} \mathrm{C}$;

c) Blotter test at $20{ }^{\circ} \mathrm{C}$ : performed using the same methodology described for the item (a), but incubated at $20^{\circ} \mathrm{C}$;

d) Rolled Paper Incubation Method: consisted in the use of a roll of germination paper (Germitest ${ }^{\circledR}$ ) measuring $28 \mathrm{~cm} \times 37.5 \mathrm{~cm}$ and previously sterilized in an autoclave at $120^{\circ} \mathrm{C}$ temperature and $1 \mathrm{~atm}$ pressure, for 20 minutes. Subsequently, sterile $\mathrm{H}_{2} \mathrm{O}$ was added in the proportion of 2.5 times the mass of the paper. Each roll was constituted of three sheets of germination paper: two sheets under the seeds and one sheet covering them. The laboratory examination was performed on 400 seed distributed in eight rolls containing 50 seeds each, which were then incubated into a germinator, at $20{ }^{\circ} \mathrm{C}$ temperature and $100 \% \mathrm{RH}$ conditions, under continuous dark. The evaluations were performed by visual observation of sclerotia formation. When their visualization was not feasible, infected seedlings and dead seeds (surrounded by the characteristic mycelia of $S$. sclerotiorum) were transferred to $11 \mathrm{~cm} \mathrm{x} 11 \mathrm{~cm}$ x $3.5 \mathrm{~cm}$ gerbox containing two sheets of filter paper, moistened with $\mathrm{H}_{2} \mathrm{O}$, in the proportion of 2.5 times the mass of the substrate. After three days incubation at 20 
${ }^{\circ} \mathrm{C}$, under a $12 / 12 \mathrm{~h}$ photoperiod (light/dark), the sclerotia formation was observed on seeds and seedlings;

e) Neon-S Method: in this assay, the substrate described by Nasser et al. (1995) using a culture medium containing the following ingredients per liter of $\mathrm{H}_{2} \mathrm{O}: 30 \mathrm{~g}$ PDA medium; $50 \mathrm{mg}$ bromophenol blue; $50 \mathrm{mg}$ chloramphenicol; and $50 \mathrm{mg}$ of free 2,4-D acid was used. The so prepared culture medium was then sterilized in autoclave, at $120^{\circ} \mathrm{C}$ and $1 \mathrm{~atm}$ pressure, for 20 min. obtaining a blue color culture medium that was poured into $9 \mathrm{~cm}$ in diameter Petri dishes, at a volume of approximately $25 \mathrm{~mL}$ per plate. Subsequently, 10 soybean seeds per Petri dish were randomly placed on top of the so called Neon-S culture medium totaling 40 plates and 400 seeds. In sequence, the plates were incubated at $20{ }^{\circ} \mathrm{C}$, in the dark. The evaluations were performed over a period of seven to 12 days. During the incubation period, the plates presenting changes in the blue color of the medium to yellow were observed under stereomicroscope to verify if the hyphae surrounding the seeds were showing the typical hyphal growth of the $S$. sclerotiorum fungus, as well as for the verification of the presence of sclerotia.

The methods were compared regarding to sensibility in detecting the fungus $S$. sclerotiorum, results repeatability, and the incidence of fungi considered undesirable during the seed analysis process.
For evaluating the sensitivity of S. sclerotiorum detection methods the percentage of seeds with the fungus presence was determined. To verify results repeatability of each method evaluated the experiment was repeated four times, analyzing 400 seeds per replication, and the results of the four experiments were compared among each other. In the evaluation of the incidence of other fungi considered undesirable during the seed analysis, it was also determined the number of seeds with the presence of those fungi.

A completely randomized experimental design, with four replications, was used in the experiment. Data were submitted to ANOVA and treatment means were compared by $t$ and Tukey tests using the SASM-Agri (Canteri, 2001) statistical program.

\section{Results and Discussion}

Results on sensitivity of the methods evaluated for detecting S. sclerotiorum in soybean seeds are shown on Table 1. Despite not showing statistically significant differences among the methods, data obtained reveal that in the soybean seeds (cv. CD 206) artificially inoculated in the laboratory the fungus $S$. sclerotiorum was detected in $100 \%$ of the seeds, using the seed health tests routinely used in seed pathology laboratories. The fungus, however, was difficult do be detected in the seeds naturally infected, i.e. seeds from lots harvested within infested areas.

Table 1. Comparison of sensitivity among methods used for detecting Sclerotinia sclerotiorum in seed samples of seven different soybean cultivars harvested in areas naturally infested with the disease white mold and one seed sample artificially inoculated with that fungus under laboratory conditions.

\begin{tabular}{|c|c|c|c|c|c|c|c|c|}
\hline \multirow[b]{3}{*}{ Methods } & \multicolumn{8}{|c|}{ Percentage of seeds } \\
\hline & \multirow[b]{2}{*}{$\begin{array}{l}\text { తి } \\
\text { ठ }\end{array}$} & \multicolumn{6}{|c|}{ Naturally infected } & \multirow{2}{*}{ 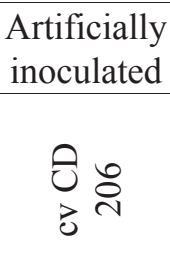 } \\
\hline & & 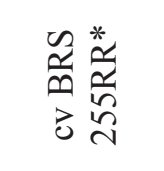 & 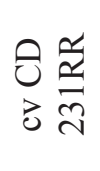 & 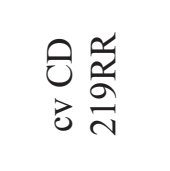 & 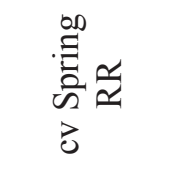 & 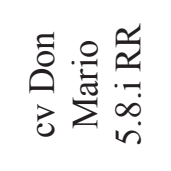 & 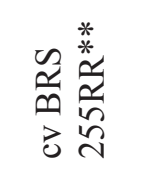 & \\
\hline Blotter Test $7{ }^{\circ} \mathrm{C}$ & $0^{\mathrm{ns}}$ & $0^{\mathrm{ns}}$ & $0^{\mathrm{ns}}$ & $0^{\mathrm{ns}}$ & $1.50^{\mathrm{ns}}(30)$ & $0.50^{\mathrm{ns}}(30)$ & $0^{\mathrm{ns}}$ & $100(14)$ \\
\hline Blotter Test $14^{\circ} \mathrm{C}$ & 0 & $0.25(30)$ & 0 & $1.00(30)$ & 0 & 0 & 0 & $100(7)$ \\
\hline Blotter Test $20^{\circ} \mathrm{C}$ & 0 & 0 & 0 & 0 & 0 & 0 & 0 & $100(7)$ \\
\hline Rolled Paper $20^{\circ} \mathrm{C}$ & $0.25(14)$ & 0 & 0 & 0 & 0 & 0 & 0 & $100(7)$ \\
\hline Neon-S $20^{\circ} \mathrm{C}$ & 0 & 0 & 0 & 0 & 0 & 0 & $0.50(7)$ & $100(7)$ \\
\hline
\end{tabular}

${ }^{\text {ns }}$ Non-significant $(\mathrm{p}>0,05)$;

( ) = Days of incubation for $S$. sclerotiorum detection;

*2008/09 crop season;

$* * 2009 / 10$ crop season. 
In a research work carried out with the white mold disease on common bean, Nasser et al. (1999) observed that the tests used for detecting $S$. sclerotiorum in commercial common bean seeds had sensitivity ranging from $0.25 \%$ to $2.30 \%$ in 400 infected seeds, emphasizing that despite the low percentage (1 in 400 seeds) such figure represents 625 primary outbreaks for disease spreading to a population of 250,000 plants.ha-1

Hoffman et al. (1998) studying seed quality of soybean produced in fields infested with $S$. sclerotiorum observed the fungus incidence level on plants ranging from 0 to $95 \%$ and verified the presence of the pathogen at level ranging from $0.3 \%$ to $0.7 \%$ in the seeds.

The literature confirms data achieved within this research work for the detection of the fungus Sclerotinia sclerotiorum in soybean seeds by the following methods: Blotter Test at $7{ }^{\circ} \mathrm{C}$, which detected the presence of $S$. sclerotiorum in $1.5 \%$ in seeds of the cv. Spring RR and $0.50 \%$ in seeds of the cv. Don Mario 5.8iRR; Blotter Test at $14{ }^{\circ} \mathrm{C}$ that detected $0.25 \%$ of the fungus in seeds of the cv. BRS 255RR from the $2008 / 09$ crop season and $1.00 \%$ in seeds of the cv. CD 219RR; Rolled Paper test, which detected the presence of $0.25 \%$ of infected seeds in the cv. CD 206; and Neon-S test, which detected $0.50 \%$ infected seeds in the cv. CD 219RR, from the 2009/10 crop season.

Table 1 shows data on days of incubation for each method studied. In the seeds artificially inoculated in the laboratory (cv. CD 206), the sclerotia were detected by the seed health tests after seven days incubation, except the Blotter Test method at $7{ }^{\circ} \mathrm{C}$ in which the detection occurred after 14 days incubation period. These results agree with those of Napoleão et al. (2006) that inoculating soybean seed with $S$. sclerotiorum detected the presence of sclerotia in five days. In the seeds harvested in naturally infested areas, however, the presence of sclerotia was detected within a seven to 30 days incubation period.

Results herein obtained may have been a consequence of the sampling method, since the same procedure applicable for collecting working samples was used as recommended by the Rules for Seed Analysis (Brasil, 2009). Perhaps this cannot be representative for the detection of pathogens present in seed lots with low infection levels, what occurs when those seed lots are obtained from plants naturally infected, as reported by several authors (Nasser et al., 1999; Morrison, 1999; Henning et al., 2009).

This could have indirectly affected the results of the seed health analysis, thus leading to false negative results, i.e. to consider that the seed lot did not contain S. sclerotiorum in the seeds, when the pathogen was actually present in the seed lot. Henning et al. (2009) verified that in 10,400 soybean seeds incubated by the Blotter Test method, only eight S. sclerotiorum infected seeds were detected. Thus, there is the possibility that the presence of the pathogen is not detected when only 400 seeds are analyzed leading to a false negative result. Therefore, there is a need for further studies on sampling methods, for that new representability parameters for detection of this pathogen in the seeds can be used.

Table 2 shows data obtained on the repeatability for each method. The values do not statistically differ among each other, but emphasize that when the same S. sclerotiorum detection method was repeated for the same seed sample; different results were achieved, thus allowing the interpretation of some results as false negative. For Sheppard (1993), the tolerance level for a false negative result depends on the pathogen epidemiological importance and on the relative value of the disease control.

Due to the relevance of the transmissibility of the white mold disease via seeds, once the detection of a single infected seed is considered as a great inoculum potential (Steadman, 1983; Mueller et al., 1999) and in face of the disease importance that, under favorable environmental conditions for its development, can drastically reduce soybean seed production, the false negative result cannot be tolerated; since there is the possibility that with the replication of the seed health test the pathogen detection can be achieved.

In relation to the presence of other undesirable fungi during the seed analyses, it can be noticed on Figure 1 that at the lowest temperature $\left(7^{\circ} \mathrm{C}\right)$ the development of these fungi, represented by Fusarium sp., Rhizophus spp., Aspergillus spp., and Penicillium spp., was very slow and they were not detected at this temperature, demanding an average of 14 days incubation and higher temperature (Figure 2). The species determination and the quantification of the other fungi present after incubation were not performed, once the manipulation of incubated seeds in the gerbox was not feasible. 
Table 2. Comparison of repeatability among methods used for Sclerotinia sclerotiorum detection in seeds of seven different soybean cultivars harvested in areas naturally infested by the white mold disease and one seed sample artificially inoculated with that fungus under laboratory conditions.

\begin{tabular}{|c|c|c|c|c|c|c|c|c|c|}
\hline \multirow[b]{3}{*}{ Method } & \multirow[b]{3}{*}{ Replication } & \multicolumn{8}{|c|}{ Number of infected seeds } \\
\hline & & \multirow[b]{2}{*}{ 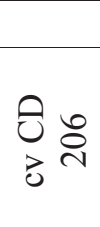 } & \multicolumn{6}{|c|}{ Naturally infected } & \multirow{2}{*}{ 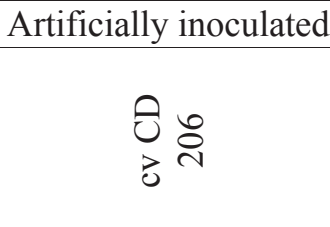 } \\
\hline & & & 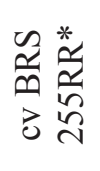 & 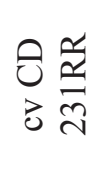 & 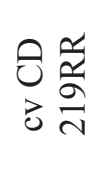 & $\begin{array}{l}\infty \\
: 0 \\
0 \\
0 \\
0 \\
0 \\
0\end{array}$ & 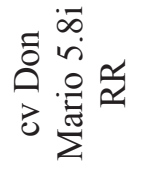 & 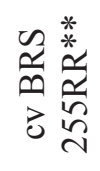 & \\
\hline \multirow{4}{*}{ Blotter Test $7{ }^{\circ} \mathrm{C}$} & $\mathrm{R} 1$ & $0^{\mathrm{ns}}$ & $0^{\mathrm{ns}}$ & $0^{\mathrm{ns}}$ & $0^{\mathrm{ns}}$ & $0^{\mathrm{ns}}$ & $2^{\mathrm{ns}}$ & $0^{\mathrm{ns}}$ & 400 \\
\hline & R2 & 0 & 0 & 0 & 0 & 6 & 0 & 0 & 400 \\
\hline & R3 & 0 & 0 & 0 & 0 & 0 & 0 & 0 & 400 \\
\hline & $\mathrm{R} 4$ & 0 & 0 & 0 & 0 & 0 & 0 & 0 & 400 \\
\hline \multirow{4}{*}{ Blotter Test $14{ }^{\circ} \mathrm{C}$} & $\mathrm{R} 1$ & 0 & 0 & 0 & 4 & 0 & 0 & 0 & 400 \\
\hline & $\mathrm{R} 2$ & 0 & 0 & 0 & 0 & 0 & 0 & 0 & 400 \\
\hline & R3 & 0 & 0 & 0 & 0 & 0 & 0 & 0 & 400 \\
\hline & $\mathrm{R} 4$ & 0 & 1 & 0 & 0 & 0 & 0 & 0 & 400 \\
\hline \multirow{4}{*}{ Blotter Test $20^{\circ} \mathrm{C}$} & R1 & 0 & 0 & 0 & 0 & 0 & 0 & 0 & 400 \\
\hline & $\mathrm{R} 2$ & 0 & 0 & 0 & 0 & 0 & 0 & 0 & 400 \\
\hline & $\mathrm{R} 3$ & 0 & 0 & 0 & 0 & 0 & 0 & 0 & 400 \\
\hline & $\mathrm{R} 4$ & 0 & 0 & 0 & 0 & 0 & 0 & 0 & 400 \\
\hline \multirow{4}{*}{ Rolled Paper $20^{\circ} \mathrm{C}$} & R1 & 1 & 0 & 0 & 0 & 0 & 0 & 0 & 400 \\
\hline & $\mathrm{R} 2$ & 0 & 0 & 0 & 0 & 0 & 0 & 0 & 400 \\
\hline & R3 & 0 & 0 & 0 & 0 & 0 & 0 & 0 & 400 \\
\hline & $\mathrm{R} 4$ & 0 & 0 & 0 & 0 & 0 & 0 & 0 & 400 \\
\hline \multirow{4}{*}{ Neon-S $20^{\circ} \mathrm{C}$} & R1 & 0 & 0 & 0 & 0 & 0 & 0 & 0 & 400 \\
\hline & $\mathrm{R} 2$ & 0 & 0 & 0 & 0 & 0 & 0 & 0 & 400 \\
\hline & R3 & 0 & 0 & 0 & 0 & 0 & 0 & 2 & 400 \\
\hline & $\mathrm{R} 4$ & 0 & 0 & 0 & 0 & 0 & 0 & 0 & 400 \\
\hline
\end{tabular}

${ }^{\text {ns }}$ Non-significant $(\mathrm{p}>0,05) ; * 2008 / 09$ crop season; $* * 2009 / 10$ crop season.

It can be also observed on Figure 1 that in the seeds artificially inoculated in laboratory (cv. CD 206; at $7{ }^{\circ} \mathrm{C}$ ) the presence of undesirable fungi was not detected due to the $S$. sclerotiorum faster growth covering totally the seeds.

It was also found that as the incubation temperature increased the undesirable fungi had a faster development and that depending on seed contamination level, in approximately seven days, 300 seed to be yet analyzed were already infected (Figures 2 and 3). Besides temperature, it was also observed that with the use of a different culture medium, as in the Neon-S method (Figure 4), the substrate was enriched, thus providing adequate conditions for the fast development of antagonistic or undesirable fungi.

By the results achieved, the Blotter Test, at $7{ }^{\circ} \mathrm{C}$ temperature, was the method showing the lowest level of undesirable fungi during the first weeks of incubation, therefore allowing the observation of sclerotia formation on the infected seeds. Such observation was impaired or non- feasible at higher temperatures, which enabled the faster development of the undesirable fungi that, depending on the growth rate of these fungi, almost covered the freshly-formed sclerotia and consequently allowing false negative results in the S. sclerotiorum detection.

Because of the high dissemination of the pathogen Sclerotinia sclerotiorum, causal agent of the white mold disease on several different field crops, that has been occurring in Brazil, probably via seeds, the improvement of detection methods for this fungus in soybean seeds, correlating them with the intensity of the disease field incidence in the country are necessary. 


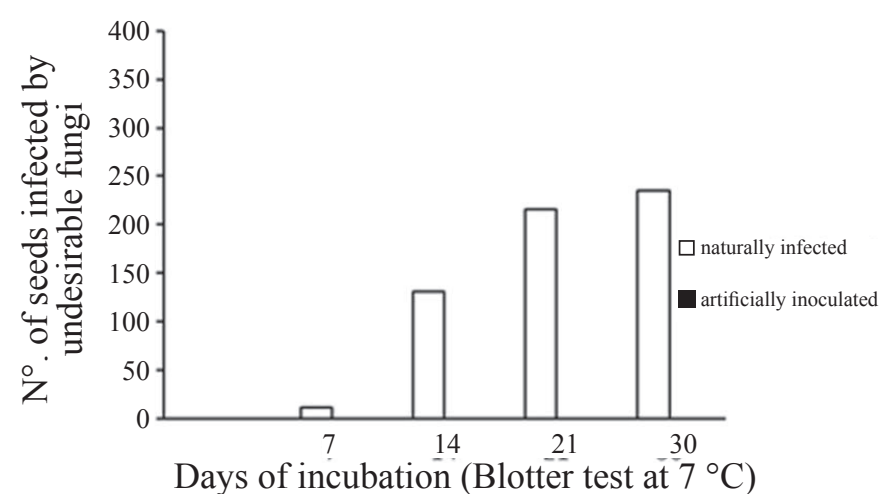

Figure 1. Number of seeds with other undesirable fungi observed by the Blotter Test method, at $7{ }^{\circ} \mathrm{C}$, correlated to days of incubation found in soybean seed samples harvested in areas naturally infested with the white mold disease and one sample artificially inoculated with its causal agent fungus Sclerotinia sclerotiorum under laboratory conditions.

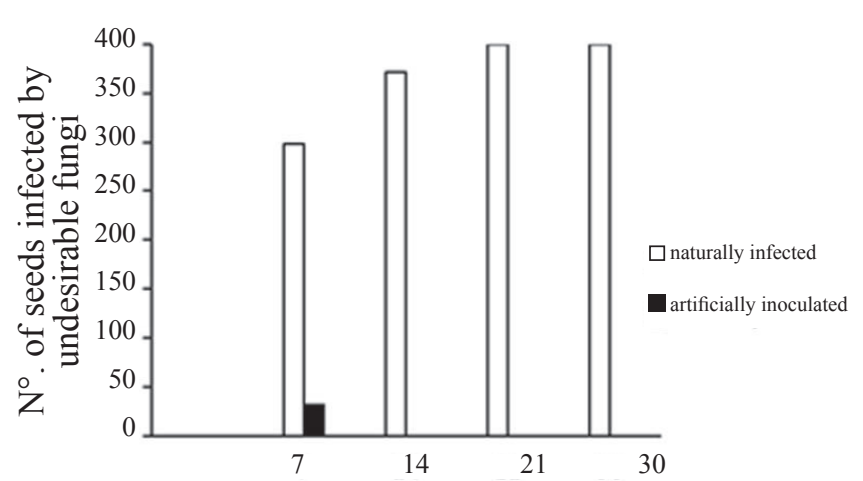

Days of incubation (Blotter test at $20^{\circ} \mathrm{C}$ )

Figure 3. Number of seeds with other undesirable fungi observed by the Blotter Test method, at $20{ }^{\circ} \mathrm{C}$, correlated to days of incubation found in soybean seed samples harvested in areas naturally infested with the white mold disease and one sample artificially inoculated with its causal agent Sclerotinia sclerotiorum under laboratory conditions.

\section{Conclusions}

For soybean seed samples harvested in areas with historic of the disease white mold, the methods: Blotter Test, with incubation temperature of $7{ }^{\circ} \mathrm{C}, 14^{\circ} \mathrm{C}$ and $20^{\circ} \mathrm{C}$; Rolled

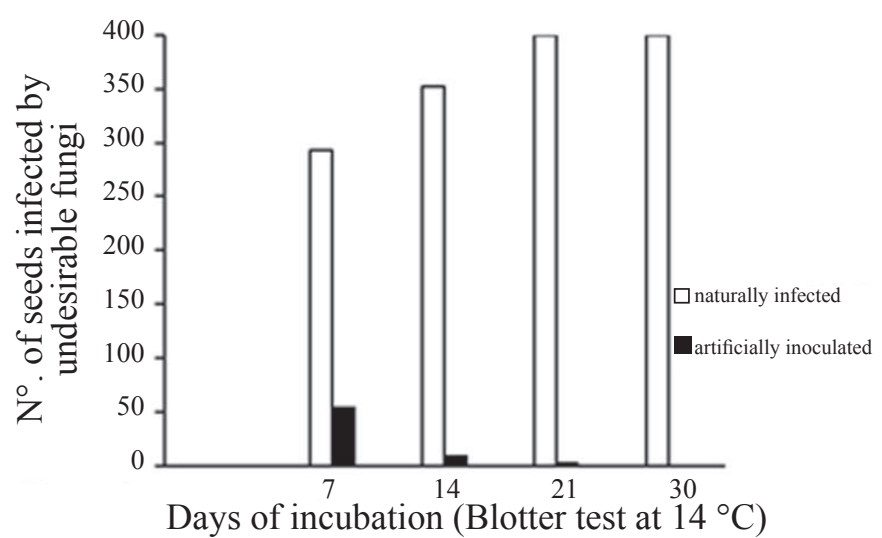

Figure 2. Number of seeds with other undesirable fungi observed by the Blotter Test method, at $14{ }^{\circ} \mathrm{C}$, correlated to days of incubation found in soybean seed samples harvested in areas naturally infested with the white mold disease and one sample artificially inoculated with its causal agent Sclerotinia sclerotiorum under laboratory conditions.

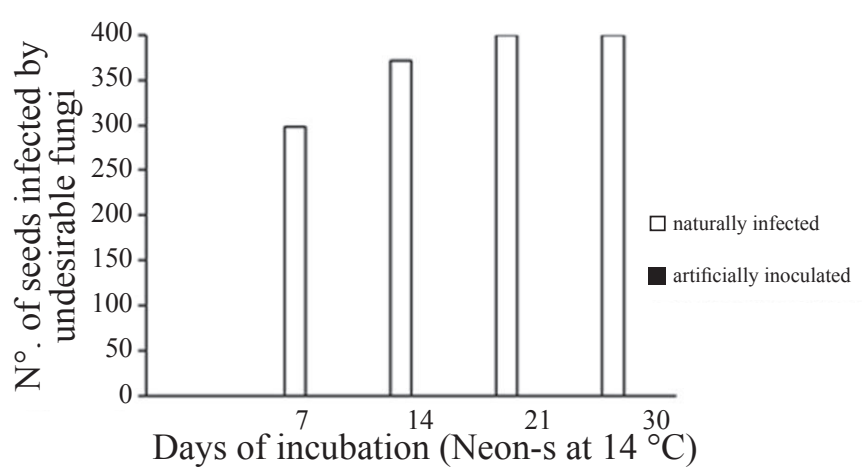

Figure 4. Number of seeds with other undesirable fungi observed by the Neon-S method, at $20{ }^{\circ} \mathrm{C}$, correlated to days of incubation found in soybean seed samples harvested in areas naturally infested with the white mold disease and one sample artificially inoculated with its causal agent Sclerotinia sclerotiorum under laboratory conditions.

Paper; and Neon-S, used for detecting the fungus Sclerotinia sclerotiorum in the seeds do not exhibit sufficient sensitivity and do not allow repeatability of results;

For samples of soybean seeds artificially inoculated in laboratory, the methods: Blotter Test with incubation 
temperature of $7{ }^{\circ} \mathrm{C}, 14{ }^{\circ} \mathrm{C}$ and $20{ }^{\circ} \mathrm{C}$; Rolled Paper; and Neon-S, used for detecting the fungus Sclerotinia sclerotiorum in the seeds are sufficiently sensitive and allow results repeatability;

The Blotter Test method, with incubation temperature of $7^{\circ} \mathrm{C}$, allows the inhibition of other undesirable fungi in seed health tests used for Sclerotinia sclerotiorum detection in soybean seed lots.

\section{Ackowledgements}

To the Conselho de Nacional de Desenvolvimento Científico e Tecnológico (CNPq) and to the Ministério da Agricultura, Pecuária e Abastecimento (MAPA) for the financial support granted to the project, Edital n ${ }^{\circ} 064 / 2008$.

\section{References}

APASSUL - ASSOCIAÇÃO DOS PRODUTORES E COMERCIANTES DE SEMENTES E MUDAS DO RIO GRANDE DO SUL-(2008) Método citado para detecção de Sclerotinia sclerotiorum em semente de soja. http://www.apassul.com.br/conteudo.asp? content $=15 \mathrm{ea}=\mathrm{detailseID}=42$ Acesso em: 4 jan. 2010.

BRASIL. Ministério da Agricultura e Reforma Agrária. Manual de análise sanitária de sementes. Ministério da Agricultura, Pecuária e Abastecimento. Secretaria de Defesa Agropecuária. Brasília, DF: MAPA/ACS, 2009. 200p. http://www.fito2009.com/fitop/manual\%20analises\%20sanitarias.pdf

CANTERI, M.G.; ALTHAUS R.A.; VIRGENS FILHO, J.S.; GIGLIOTI, E.A.; GODOY, C.V. SASM-Agri: Sistema para análise e separação de médias em experimentos agrícolas pelos métodos Scott - Knott, Tukey e Duncan. Revista Brasileira de Agrocomputação, v.1, n.2, p.18-24, 2001. http://www.agrocomputacao.deinfo.uepg.br/dezembro_2001/Arquivos/ RBAC_Artigo_03.pdf

CONAB - COMPANHIA NACIONAL DE SAFRA BRASILEIRA. Acompanhamento de safra brasileira: grãos, sexto levantamento, Brasília: Conab, 2011.40p. http://www.conab.gov.br/OlalaCMS/uploads/ arquivos/11_03_10_09_03_02_boletim_marco-11[1].pdf. Acesso em: 26 mar. 2011

EMBRAPA - EMPRESA BRASILEIRA DE PESQUISA AGROPECUÁRIA. Tecnologias de produção de soja - região central do Brasil - 2009 e 2010.- Londrina: Embrapa Soja: Embrapa Cerrados : Embrapa Agropecuária Oeste, 2008. 262p. (E rina: Embrapa, Soja, 2005. 52p. (Embrapa-Soja. Documentos, 264).

HENNING, A.A.; PAULA, F.Y.H.; MOMTEMEZZO, C.A.O.; BOSSE, E.J.; BERGONSI, J.S.S. Avaliação de princípios ativos para o controle químico de mofo branco (Sclerotinia sclerotiorum) em soja - safra 2008/2009. Informativo ABRATES, v.19, n.1, p.29-31, 2009. http://www. abrates.org.br/portal/images/stories/informativos/v19n1/artigo01.pdf
HOFFMAN, D.D.; HARTMAN, G.L.; MUELLER, D.S.; LEITZ, R.A.; NICKELL, C.D.; PEDERSEN, W.L. Yield and seed quality of soybean cultivars infected with Sclerotinia sclerotiorum. Plant Disease, v.82, n.7, p.826-829, 1998. http://apsjournals.apsnet.org/doi/pdf/10.1094/ PDIS.1998.82.7.826

JACCOUD-FILHO, D.S.; VENANCIO, W.S.; COLTURATO, A B.; HENNEBERG, L. Avaliação sanitária de sementes de soja provenientes de plantas mortas por apodrecimento radicular. Revista Fitopatologia Brasileira, v.27, p.120- 121. 2002.

JACCOUD FILHO, D.S.; MANOSSO NETO, M.O.; VRISMAN, C.M.; HENNEBERG, L.; GRABICOSKI, E.M.G.; PIERRE, M.L.C.; BERGER NETO, A.; SARTORI, F.F.; DEMARCH, V. B.; ROCHA, C.H. Análise, Distribuição e Quantificação do "Mofo Branco" em Diferentes Regiões Produtoras do Estado do Paraná: REUNIÃO DE PESQUISA DE SOJA DA REGIÃO CENTRAL DO BRASIL, 31., 2010, DF. Brasília. Resumos... Brasília: Embrapa-Soja, 2010, 226-228p.

KOCH, E.F.A.; MENTEN, J.O.M. Método alternativo para detecção de Sclerotinia sclerotiorum em sementes de feijoeiro. Summa Phytopathologica, v.26, n.2, p. 276-279, 2000.

MACHADO, J.C. Patologia de sementes: significado e atribuições. In: Carvalho, N.M. e Nakagawa, J. (Eds.). Sementes: ciência, tecnologia e produção. Jaboticabal: FUNEP, 2000.p. 522-588

MACHADO, J.C.; OLIVEIRA, J.A.; VIEIRA, M.G.G.C.; ALVES, M.C. Inoculação artificial de sementes de manitol. Revista Brasileira de Sementes, v.23, n.2, p.95-101, jul./dez. 2001. http://www.abrates.org.br/ revista/artigos/2001/v23n2/artigo13.pdf

MORRISON, R.H. Sampling in seed health testing. Phytopathology, v.89, p.1084-1087, 1999. http://apsjournals.apsnet.org/doi/pdf/10.1094/ PHYTO.1999.89.11.1084

MUELLER, D.S.; HARTMAN, G.L.; PEDERSEN, W.L. Development of sclerotia and apothecia of Sclerotinia sclerotiorum from infected soybean seed and its control by fungicide seed treatment. Plant Disease, v.83, p.1113-1115, 1999. http://apsjournals.apsnet.org/doi/abs/10.1094/ PDIS.1999.83.12.1113

NAPOLEÃO, R.; NASSER, L.C.B.; LOPES, C.A.; CAF, FILHO, A.C. Neon-S, a new medium for detection of Sclerotinia sclerotiorum on seeds. Summa Phytopathologica, v.32, n.2, p.180-182, 2006. http://www.scielo. br/scielo.php?script=sci_arttext\&pid=S0100-54052006000200014

NASSER, L.C.B.; NAPOLEÃO, R.; CARVAJAL, R.A. Mofo branco cuidado com a semente. Revista Cultivar Grandes Culturas, São Paulo, n.4, mai.1999. file:///C:/Documents\%20and\%20Settings/Helena/Meus\%20 documentos/C1\%C3\%A1 udio\%20-\%20UEPG/Est\%C3\%A1 gio/ Sclerotinia/artigo.asp.html. Acesso em: 23 mai. 2008.

NASSER, L.C.B.; BOLAND, G.J.; SUTTON, J.C. Meio semi-seletivo para detecção da viabilidade de escleródios de Sclerotinia sclerotiorum. Revista Fitopatologia Brasileira, v.20, p.376, 1995. 
PARISI, J.J.D.; PATRÖCIO, F.R.A.; OLIVEIRA, S.H.F. Modification of the paper towel seed health test for the detection of Sclerotinia sclerotiorum in bean seeds (Phaseolus vulgaris L.). Summa Phytopathologica, v.32, n.3, p.288-290, 2006. http://www.scielo.br/scielo.php?script=sci_ arttext\&pid=S0100-54052006000300015\&lng=en\&nrm=iso

SHEPPARD, J.W. Diagnostic sensitivity, specificity and predictive values in evaluation of new test. Methods. In: PROCEDEDINGS $1^{S T} I S T A$ PLANT DISEASE COMMITTEE SYMPOSIUM ON SEED HEALTH TESTING, 1993, Ottawa, Canada, p.132-142.

SOAVE, J.; WETZEL, M.M.V.S. Patologia de Sementes. Campinas: Fundação Cargill. 1987. 480p.

STEADMAN, J.R. White mold - a serious yield-limiting disease of bean. Plant Disease, v.67, p.346-350, 1983.
SUN, P.; YANG, X.B. Light, temperature, and moisture effects on apothecium production of Sclerotinia sclerotiorum. Plant Disease, v.84, n.12, p.1287-1290, 2000. http://apsjournals.apsnet.org/doi/ pdfplus/10.1094/PDIS.2000.84.12.1287

YANG, X.B.; WORKENEH, F.; LUNDEEN, P. First report of sclerotium production by Sclerotinia sclerotiorum in soil on infected soybean seeds. Plant Disease, v.82, p.264, 1998.

ZAMBOLIM, L. Teoria da transmissão de patógenos fúngicos por sementes. In: ZAMBOLIM, L. Sementes qualidade fitossanitária. 22.ed. Cap. 4. Viçosa: UFV/DFP, p.75-112, 2005. 